\title{
GOLDEN EAGLE UNSUCCESSFULLY ATTACKS PRONGHORN FAWN
}

GREG WAGNER, Faculty of Environmental Design, University of Calgary, 2500 University Drive N.W., Calgary, AB T2N 1N4

The Golden Eagle is known to prey on a variety of larger mammals, including adult and young Pronghorns. ${ }^{1,2,3,4}$ The following observation is of an unsuccessful attack by an immature Golden Eagle on a young Pronghorn fawn.

On the afternoon of 4 June 1995, I was traveling in my truck along a prairie trail through native mixed grass prairie rangeland approximately $15 \mathrm{~km}$ northwest of Bow City, Alberta. This area, on the western end of Ducks Unlimited Canada's Medicine Wheel project, consists of undulating terrain located on a plateau south and east of the Bow River. Over a period of about two hours I frequently observed one or more immature Golden Eagles circling overhead. I also encountered a number of lone Pronghorn does and two does with fawns.

One lone doe was standing at the edge of an ephemeral wetland in a small depression roughly $30 \mathrm{~m} \times 30 \mathrm{~m}$ in size. The wetland, dry at this time of year, supported taller grass than the surrounding prairie. The doe was about $60 \mathrm{~m}$ from the trail and I stopped briefly to watch her. She seemed little bothered by my presence and stayed in place while I drove off. She was lost from sight when I drove around a nearby hill.

I proceeded down the dirt trail for approximately ten minutes when I came to a dead end and headed back on the trail towards the Pronghorn. As I approached the hill, I saw an immature eagle diving towards the ground near where I had observed the doe. The hill blocked my view of the eagle's attack, but when I made my way around the hill, I saw the eagle sitting in the short grass upland about $20 \mathrm{~m}$ from the doe.

As I rounded the corner, the doe charged the eagle with her head down. This sent the eagle into flight. It rose about $30 \mathrm{~m}$ into the air and then dove into the taller grass in the depression behind the Pronghorn. The doe then turned around and began to walk towards, but not charge the eagle. Her approach sent the eagle into flight, but again it only rose only about $30 \mathrm{~m}$ into the air before making another dive into the taller grass. The doe again slowly approached the eagle, sending it aloft to about the same height. It dove into the tall grass again, only to take flight following another approach from the doe.

After this third flight from the tall grass, the eagle remained overhead for several minutes. During this time, a young fawn got up from the tall grass and walked toward the doe, who was standing on the short grass upland. After the fawn joined the female, the eagle landed on the shorter prairie about $15 \mathrm{~m}$ from the Pronghorns. It stood there for a couple of minutes before the doe, with the fawn at her side, slowly walked toward the eagle. This action prompted the eagle to take flight, this time leaving the area. I watched the mother and fawn for about half an hour after that. They remained in the area during the entire period and no more attacks from the eagle were observed. 
1. Beale, D. M. and A. D. Smith. 1973. Mortality of Pronghorn Antelope fawns in western Utah. Journal of Wildlife Management 37:343-352.

2. Bent, A. C. 1961. Life Histories of North American Birds of Prey, Part One. Reprinted from Smithsonian Institution, United States National Museum Bulletin 167, 1937. Dover Publishing Inc., New York.
3. Bruns, E. H. 1970. Winter predation of Golden Eagles and Coyotes on Pronghorn Antelopes. Canadian Field Naturalist 84:301-304.

4. Lehti, R. W. 1947. The Golden Eagle attacking Antelope. Journal of Wildlife Management 11:348-349.

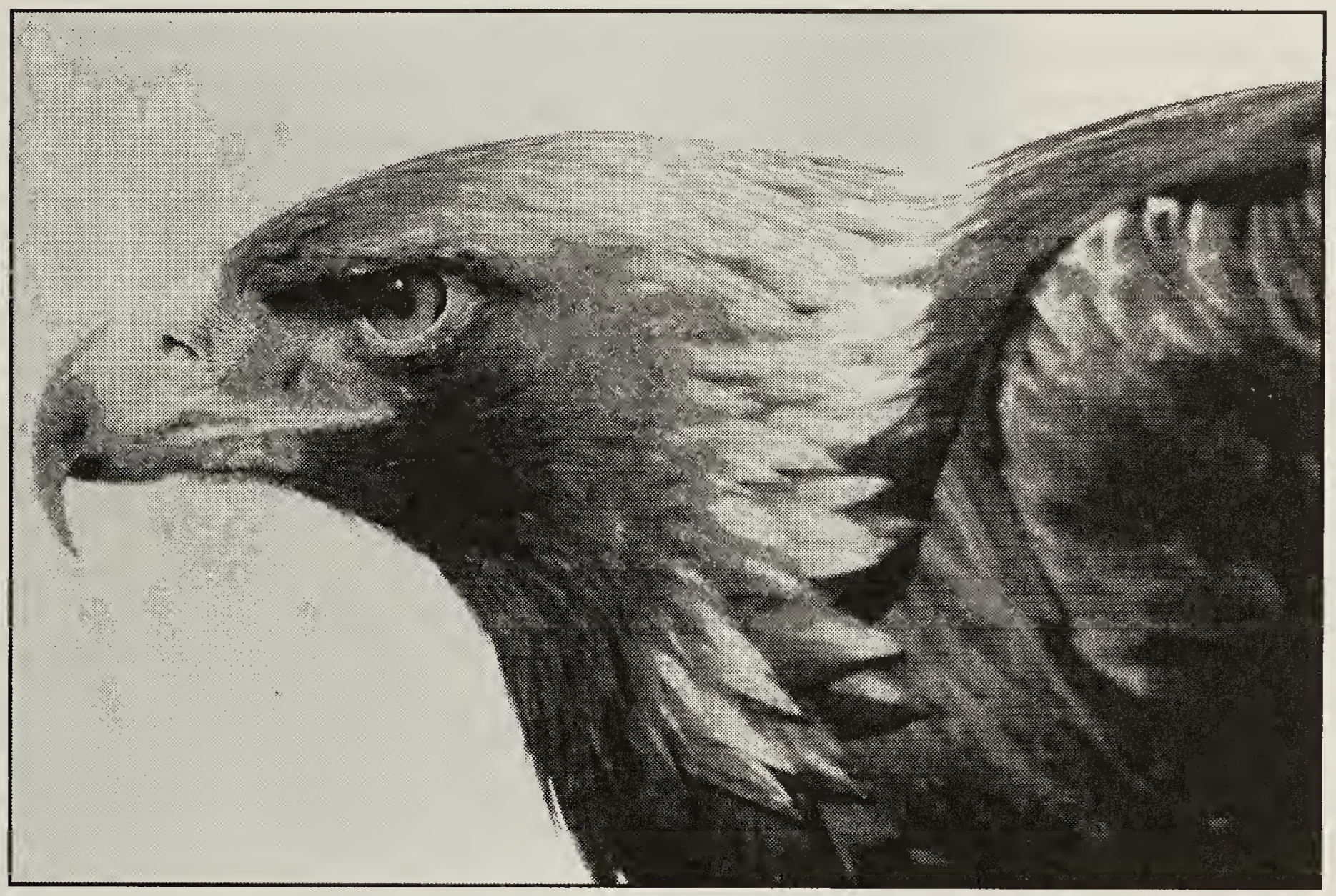

Golden Eagle

Wayne Lynch

"A Yellow-billed Magpie's nest that Verbeek (1973) dismantled, consisted of 1573 sticks and weighed $11 \mathrm{~kg}$, some 70 times the weight of the bird. The only comparable information for Black-billed Magpies comes from a single nest examined by Anders Moller (pers. comm.) in Denmark. This nest consisted of 598 sticks, weighed $4.6 \mathrm{~kg}$, and measured $44 \times 38$ × $70 \mathrm{~cm}$ high."

T. R. Birkhead, The Magpies p.141 